\title{
Pemaliq Words of Human Death within the Society of Sasak-Indonesia: A Linguistic Anthropology Study
}

\author{
Suliadi \\ Udayana University, Bali, Indonesia \\ I Ketut Darma Laksana \\ Udayana University, Bali, Indonesia \\ Mahyuni \\ Mataram University, Lombok, Indonesia \\ I Wayan Simpen \\ Udayana University, Bali, Indonesia
}

\begin{abstract}
This study aimed to describe the world's view and cultural values conceptualized by the community of Sasak on pemaliq words of human death. Non-participatory observation and in-depth interview methods were used to collect the data. The data were analyzed using a qualitative descriptive approach. It applied Miles and Huberman analysis model consisting of data collection, data reduction, data display, and conclusion. The results of the study showed that pemaliq words of human death used by the Sasak community in Sigar Penjalin Village, North Lombok Regency, Indonesia, reflected the perspective of the ancestors in understanding the nature of death. It means those who experience death are the physical matters, while the human spirits keep on living and they are in a holy place, namely in alam alus (subtle world). The Sasak community of Sigar Penjalin Village forbid the use of matè 'died' as a word for human death, not only it is considered impolite, but it is believed in bringing tulah manuh 'misfortune' to those who are using that particular word. Therefore, the ancestors of the Sasak community in Sigar Penjalin Village is in practice of using certain words as a way of avoidance, namely the word adèq 'nonexistence', ngènangang 'leaving', and ulèq 'returning home' (euphemistic words), in which all are used to represent the word matè 'died'. Cultural values reflected in the use of those words, namely the values of religiosity, consciousness, and politeness.
\end{abstract}

Index Terms-Pemaliq, world's view, cultural values, and linguistic anthropology

\section{INTRODUCTION}

Interdiction or taboo has become part of the culture and rooted within the Indonesian community. The production and usage of things that are taboos prove that the Indonesian communities have their own perspectives in understanding reality. It relates to understanding things that must not be done because they are considered endangering the communities. In other words, the ancestors of the Indonesian community since ancient time have produced specific rules that limit and control the lives of every individual; controlling words, actions, and behaviors to prevent people from using arbitrary words and perform arbitrary actions and behaviors.

The interdiction or taboo in every region in Indonesia is known by different terms. In Sasak community, Lombok Island, it is known as pemaliq. The Sasak community used pemaliq as a medium of communication expression that contains taboos in saying certain words, behaving disrespectfully, and acting arbitrarily. It means pemaliq is made into a local rule that must not be violated (Hakim, 2008, p. 298; 2015, p. 342 and Selake, 2011, p. 31). Moreover, pemaliq is used by Sasak community as a powerful energy source to shape its personality. Therefore, the Sasak community considered their production of pemaliq as one of the cultural products containing a valuable and essential concept of thought that can be used as a guidance and principle in performing communication, behavior, and action (see Koentjaraningrat, 2015, p. 153; Uhi, 2016, p. 76-77; Daeng, 2008, p. 46). This consideration means that pemaliq words have cultural meanings and values that can be applied in managing life.

Concerning this short article, the writer will explain pemaliq words of human death. As have been stated, the words are produced and used by the Sasak community, Sigar Penjalin Village, North Lombok Regency, Indonesia. In this case, the practice of using pemaliq words of human death is considered a taboo language. This language is a form of manifestation on the concept of the ancestors' understanding within Sasak community in Sigar Penjalin Village towards the mystery of human existence. Moreover, the production and expression of pemaliq words of death is a manifestation of cultural values that can be applied in managing life, especially in the form of politeness and courtesy. Hence, the 
practice of using pemaliq words of death is seen as a taboo language that reflects the avoidance of the utterance of certain inappropriate words referred to the people who passed on due to those words are considered to be harmful (see Wardhaugh, 2010, p. 249; Douglas, 2001, p. 4). In other words, certain words that are considered inappropriate to be uttered for those who passed on can result in adverse impact to those who spoke them; they will experience misfortunes within their lives (Yusuf \& Yusuf, 2014, p. 21). The misfortune may occur due to the arrogance of the speakers' unwillingness to respect and honor those who passed on. It means that the practice of using pemaliq words of death can fall into a method of forming moral behavior (see Allan \& Kate, 2006, p. 1; Freud, 2001, p. 22; and Laksana, 2009 , p. 65).

In Indonesia, studies on taboos related to death had been carried out by previous researchers, for example, the studies conducted by Barus et al. (2018) on "Linguistic Taboos in Karonese Culture", and Laksana (2009) on "Tabu Bahasa: Salah Satu Cara Memahami Kebudayaan Bali". These studies still focus on issues regarding the type/form, function and the meaning of taboo language, also the method of avoiding forbidden words. However, these studies have not highlighted another aspect of taboo language that is considered very important, namely the cultural values contained in each taboo language.

Based on the explanation above, pemaliq words of death practiced by the Sasak community in Indonesia have become an interesting object to be studied deeply and comprehensively. Therefore, the essence of this short article aims to describe the speaker's world point of view and cultural values reflected in the expression of the lingual forms of pemaliq words of death.

\section{THEORETICAL FRAMEWORK}

The researcher applied linguistic anthropology theory for this research. Linguistic anthropology is the theory that examines the role and meaning of a language that builds a culture (Foley, 1997, p. 3; 2016, p. 251). In other words, linguistic anthropology investigates the practice on the use of a language that forms and gives meaning to culture (see Salzman, Stainlaw, \& Adachi, 2012, p. 14-25; Danesi, 2004, p. 7; Crystal, 2008, p. 27; and Sibarani, 2014, p. 314; 2015; 2004).

Furthermore, Duranti (1997, p. 2) also asserted that linguistic anthropology is a study of language as a cultural resource and speaking as a cultural practice. Thus, Duranti (1997, p. 3-4) emphasized that the concept of a language in linguistic anthropology as a symbolic source used in social and communication settings has a vital role in manifesting the real and unreal world's view or the aspect of ideational and material that realize the existence of the human being (cf. Palmer, 1996; Geert, 1973, p. 10-12). Therefore, the language features that create pemaliq of death are considered as conceptualization codes that are embedded within the social construction and had become a reflection of the human experience (Sharifian, 2017, p. 2). The language feature that objectifies pemaliq words related to death influenced Sasak community's view on the reality of life and their personality (see Astawa, Budiarsa, \& Simpen, 2019). To that, this justifies Wang \& Jia (2016) perspective that the use of language within a culture can give an understanding of the production of the culture itself in regards to reality and itself.

\section{RESEARCH METHOD}

This research was conducted within the indigenous community of the Sasak in Sigar Penjalin Village, North Lombok Regency, Indonesia. This research is descriptive qualitative research that describes lingual expression data. The data expressed manifests pemaliq words of death in a narrative manner. The data was obtained through the method of indepth interviews and non-participatory observation. The collected data was analyzed using Miles and Huberman's (1994, p. 10-12) flow path models. The models consisted of four, namely: data collection, data reduction, data display and conclusion. (1) data collection; collecting utterances expressing taboos that are mentioning death and the use of evasion words; (2) data reduction; simplifying and adjusting the data by only selecting data that are related to pemaliq words of human death; (3) data display; presenting the data in the form of lingual expression that showed the interdiction of mentioning the human death. In addition, this section also describes the content of the evasion words that are used to replace the avoided words, exploring the meaning and cultural values embedded in evasion words based on ethic and emic approaches; and (4) conclusions; drawing conclusions from the perspective of Sasak community in Sigar Penjalin Village towards the mystery of human existence.

\section{RESULTS AND DISCUSSIONS}

The community of Sasak in Sigar Penjalin Village considered the behaviors of mutual respect and honor between human beings are not limited only to the people but also to those who passed on. In this case, the Sasak community in Sigar Penjalin Village produced specific rules that can be used in respecting them. The rules applied to those people are known as pemaliq that must not be violated, and if so it is believed to bringing tulah manuh a 'misfortune', for instance, it is taboo to name the process of a dead person with the word matè 'die'. See the example in the following pemaliq expression.

(1) Deq kanggo ny-(s)ebut matè tau siq ngènangang NEG allow DA-say to die people REL dead 
'It is not allowed to use the word 'die' for the dead people'

The pemaliq expression above illustrates that Sasak community in Sigar Penjalin Village has forbidden the usage of the word matè 'die' in referring to human death. The word 'matè' in this case, is considered inappropriate to be applied to humans. Its meaning is believed to be less polite and has a low sense of values. The utterance is improper to be heard by the people, primarily if heard by the family of the ones who passed on. Hence, the word mate 'die' itself refers to the death of animals or plants. Thus, if the word matè 'die' is used for human death, then humans are considered animals. To distinguish between the death of humans and the death of animals or plants, the ancestors of Sasak community in Indonesia had produced and used specific words to replace the use of the word matè 'die', that is, using euphemistic words such as adèq, ngènangang, and ulèq.

The word adè lexically means 'non-existence'. This word is categorized as adverbial, a word that describes the state of things. The word adè is used when a person is dying or several minutes after passing away. This word is usually uttered by a kiai or a religious figure who checks on the condition of the dying person. It is to ensure whether s/he is still alive or not. In this case, when a dying person is truly dead, then a kiai will announce the death of a dying person to all the family members. Regarding the above situation, the word adè in this context is known as a word that refers to the soul of the deceased who had left his physical body. In other words, the spirit that livens up the physical matter of a human is adè 'no longer existing' within the human body. See the data below:

(2) Wah adèq-nya, Inaq Samenah ni

Already NEG PRON-3, Mrs Samenah this

'Mrs. Samenah is no longer existing'

The sentence above was uttered by a religious leader who examined Inaq Samenah's condition to reassure whether she was still alive or already passed away. In this case, when the physical matter of Inaq Samenah had shown no sign of living, which was proven by the non-existence of her pulse and breath, the religious leader who examine her condition then informed her relatives that she had passed away. Thus, the word adè 'no longer existing' uttered by the religious leader on data 2 refers to the fact that the soul of Inaq Samenah no longer existed in her physical matter.

Meanwhile, the word ngènangang is a word categorized as a verb and in a syntactic structure, always functions as a predicate. Morphologically, the word ngènangang is formed by the addition of the confix $\{n g$ - ang $\}+\dot{e} n a n g \rightarrow$ ngènangang, which lexically means 'leaving'. The word ngènangang is usually uttered by penyilaq; a person who is in charge of informing a person's death to a relative or other people, and at the same time inviting them to attend the prayer and the funeral. See the example of the use of the word in the data below:

(3) A : Aku kte berain diq seninan man Salik nu ngènangang

PRON-1 here tell PRON-2, wife uncle Salik that leaving

'I'm here to tell you that uncle Salik's wife had left/passed away'

$\mathrm{B}$ : Sekumbèan ia ngènangang?

When PRON-3 leaving

'When exactly did she pass away?'

A : Tonèq lemaq

Just now morning

'This morning'

Data (3) showed that speaker A is penyilaq who informed the death of uncle Salik's wife to speaker B. In this case, when speaker A informed the news to speaker B he used the word ngènangang, which was then also being used by speaker B after receiving the information from speaker A. However, the word ngènangang within the understanding concept of Sasak community in Sigar Penjalin Village is actually a word that informs the spirit's departure of the deceased to return to God. In this case, the Sasak community of Sigar Penjalin Village understood that the departure a person to meet his Creator has ngènang 'left' his physical matter, leaving all family, relatives, and loved ones forever. To leave a physical matter here means that the human spirit that has departed will leave its body to be in eternal life. Furthermore, the context of leaving the family, relatives, and loved ones illustrates that the person who passed on travels earlier to real life. In other words, this world is claimed to be a terminal for everyone waiting for a vehicle or to be picked up, which will take them to a place as the final destination. In this regard, those who passed on earlier are those who were picked up earlier to be taken into the place of his final destination.

The following word ulèq is a word categorized as a verb, which lexically means 'returning home'. Concerning death, the word ulèq illustrates that a person who died is an actor (subject) who travels ulèq back home from a place to its origin or original residence. For more explanation, look at the data below:

(4) Cukup wah menangis, ikhlasang seninan diq teger tenang ulèq!

Enough already crying, be sincere wife PRON-2 so peaceful returning home

'Stop crying, you have to let your wife go sincerely so she can return home peacefully!'

Data (4) showed that a speaker was advising a man who was left by his wife. The sentence reflected that the speaker was trying to give comfort, strength, and understanding to the man that his wife is actually on a journey of ulèq 'returning home' to her origin/the place where she once came from. In this context, those who passed on have returned to their owners, to God the Creator. Hence, it can be emphasized that the word ulè reflects the understanding of Sasak community in Sigar Penjalin Village that this world is not an eternal place; however, it is only a temporary place or a 
stop for the route to eternity. The place of eternity for the deceased in this case is in the alam alus (subtle world) (cf. Budiwanti, 2000, p. 145).

The understanding of Sasak community in Sigar Penjalin Village, which is conceptualized in the practice of using the words adèq, ngènangang, and ulèq as references to the word matè 'die' as explained above, is related to the understanding of the three worlds of human life. The sasak community of Sigar Penjalin Village conceptualizes the three worlds of human life into (1) alam peteng (in the womb), (2) alam benah (in the real world), and (3) alam alus (the world after death).

Alam peteng (in the womb) is the starting point of human life, and it is believed to be the place where humans received the orders and decisions of the Creator. Furthermore, the received command in that world will be practiced by humans after being born into the next phase of life; alam benah (the real world). In this case, alam benah (the real world) is seen as a place where humans actualize their existence as servants. As the servants, humans must obey the orders and stay away from things prohibited by the Creator. Furthermore, alam benah (the real world) is also understood as a waiting place for being picked up to the third world, which is alam alus; the subtle world as the final destination for facing the Creator. Thus, the three worlds of human life essentially describe the journey of human life itself, in which initially starting from the subtle world (alam peteng) to the real world (alam benah) and returning to the subtle world (alam alus). In other words, the three worlds of human life understood by Sasak community of Sigar Penjalin Village are the understanding of the existence and non-existence of human beings.

The explanation of the evasion words in the form of euphemism words above reflected that pemaliq words of death contain cultural values that can be applied in managing life. The cultural values of pemaliq words of death consist of the value of religiosity, the value of consciousness and politeness. The value of religiosity is the value that describes the belief in human existence as a creature created by God and will return to God. The value of consciousness is the value that represents human consciousness in understanding the presence of its physical body only as an outer layer that will get damaged and becoming soil again. Meanwhile, politeness is the use of kind words, words that have a high sense of values and are appropriate to be uttered to all human beings, even to those who passed on.

\section{CONCLUSION}

Based on the discussion above, it can be inferred that pemaliq words of human deaths, which are being used by Sasak community in Indonesia, have shown that there are perspectives or concepts in understanding the nature of human existence. In this case, the ancestors of the Sasak community had conceptualized their views on the nature of human existence through lingual items that express pemaliq words of death, especially on euphemistic evasion words.

Pemaliq words of death are the local rules produced by the ancestors as a mean of control to avoid the occurrence of arbitrariness in a speech to prevent the happening of misfortune. In other words, pemaliq words of death are used to create mutual respect and honor among human beings even to those who passed on because the essence of the person's death is the deceased of his physical matter, while his soul will stay alive.

\section{ACKNOWLEDGMENTS}

I want to express my gratitude to Lalu Abdi Kamil and Lalu Hamzah, the leaders of Sasak community in Sigar Penjalin Village, North Lombok Regency, Indonesia, who have provided many directions, data, and content on pemaliq words of human death.

\section{REFERENCES}

[1] Allan, Keith and Kate, Burridge. (2006). Forbidden Words: Taboo and the Censoring of Language. Cambridge, etc.: Cambridge University Press.

[2] Astawa, I. G., Budiarsa, M., \& Simpen, I. W. (2019). The Representation of The Tri Hita Karana Ecosophy in The Awig-awig (Customary Law) Text of Tenganan Pegringsingan Village: Critical Ecolinguistics Perspective. Journal of Language Teaching and Research, 10(2), 396. https://doi.org/10.17507/jltr.1002.23.

[3] Barus, et al. (2018). Linguistic Taboos in Karonese Culture. In The $1^{\text {st }}$ Annual International Conference on Language and Literature, KnE Social Sciences, 411.-421.

[4] Budiwanti, Erni. (2000). Islam Sasak: Wetu Telu Versus Wetu Lima. Translated by Noor Cholis. Yogyakarta: LKis.

[5] Crystal, David. (2008). A Dictionary of Linguistics and Phonetics. USA: Blackwell Publishing.

[6] Daeng, Hans J. (2008). Manusia, Kebudayaan, dan Lingkungan: Tinjauan Antropologi. Yogyakarta: Pustaka Pelajar.

[7] Danesi, Marcel. (2004). A Basic Course in Anthropological Linguistics. Toronto: Canadian Scholars' Press Inc.

[8] Douglas, Mary. (2001). Purity and Danger: An Analysis of the Concepts of Pollution and Taboo. London and New York: Routledge-the Taylor \& Francis Group.

[9] Duranti, Alessandro. (1997). Linguistic Anthropology. Cambridge: Cambridge University Press.

[10] Foley, William A. (1997). Anthropological Linguistics: An Introduction. Malden \& Oxford: Blackwell Publisher Ltd.

[11] Foley, William A. (2016). Anthropological Linguistics and Field Linguistics. In Keith Allan (eds.), The Routledge Handbook of Linguistics. London \& New York: Routledge, 250-263.

[12] Freud, Sigmund. (2001). Totem dan Tabu. Translated from Totem dan Taboo by Kurniawan Adi Saputro. Yogyakarta: Jendela Grafika.

[13] Geertz, Clifford. (1973). The Interpretation of Cultures. New York. Basic Books, Inc., Publishers. 
[14] Hakim, Lukmanul et al. (2008). Kamus Sasak-Indonesia. Kantor Bahasa Provinsi NTB: Badan Pengembangan dan Pembinaan Bahasa Kementerian Pendidikan dan Kebudayaan.

[15] Hakim, Lukmanul et al. (2015). Kamus Sasak-Indonesia. Kantor Bahasa Provinsi NTB: Badan Pengembangan dan Pembinaan Bahasa Kementerian Pendidikan dan Kebudayaan.

[16] Koentjaraningrat. (2015). Pengantar Ilmu Antropologi. Jakarta: Rineka Cipta.

[17] Laksana, I Ketut Darma. (2009). Tabu Bahasa: Salah Satu Cara Memahami Kebudayaan Bali. Denpasar: Udayana University Press.

[18] Miles, Matthew B \& Huberman, A. Michael. (1994). Qualiative Data Analysis. London: SAGE Publications.

[19] Palmer, G. B. (1996). Toward a theory of cultural linguistics. Austin: University of Texas Press.

[20] Salzman, Zdenek., Stainlaw, James M., \& Adachi, Nobuko. (2012). Language, Culture, and Society: An Introduction to Linguistic Anthropology. United State of America: Westview Press.

[21] Sharifian, Farzad. (2017). Cultural Linguistics: Cultural Conceptualisations and Language. Amsterdam/Philadelphia: John Benjamins Publishing Company.

[22] Sibarani, Robert. (2004). Linguistik antropologi: Antropologi Linguistik-Linguistik Antropologi. Medan: Poda.

[23] Sibarani, Robert. (2014). Kearifan Lokal: Hakikat, Peran, dan Metode Tradisi Lisan. Jakarta: Asosiasi Tradisi Lisan (ATL).

[24] Sibarani, Robert. (2015). Pembentukan Karakter: Langkah-Langkah Berbasis Kearifan Lokal. Jakarta: Asosiasi Tradisi Lisan (ATL).

[25] Slake, Kurdap. (2011). Mengenal Budaya dan Adat Istiadat Komunitas Suku Sasak di Desa Tradisional Sade. Mataram: Dinas Kebudayaan dan Pariwisata Provinsi Nusa Tenggara Barat.

[26] Uhi, Jannes Alexander. (2016). Filsafat Kebudayaan: Konstruksi Cornelis Anthonie van Peursen dan Catatan Reflektif. Yoyakarta: Pustaka Pelajar.

[27] Wardhaugh, Ronald. (2010). An Introduction to Sociolinguistics. Singapore: Wiley-Blackwell.

[28] Wang, J., \& Jia, J. (2016). Analysis of Symbolic Meanings between Chinese and English Food Proverbs from the Perspective of Cultural Linguistics. Journal of Language Teaching and Research, 7(2), 415. https://doi.org/10.17507/j1tr.0702.24.

[29] Yusuf, Y. Q., \& Yusuf, Q. (2014). Contemporary Acehnese cultural prohibitions and the practice of mystical threats. Kemanusiaan, 21(2), 21-53.

Suliadi was born in Lombok, Indonesia. He accomplished his master degree in 2016 focusing on the Indonesian Language at Mataram University, Lombok, Indonesia. He is currently registered as a doctoral candidate in linguistics at Udayana University majoring in anthropology linguistics studies.

I Ketut Darma Laksana is a senior professor in Linguistics at Udayana University, Bali, Indonesia. He accomplished his master degree in 1994 and doctoral degree in 2003 at the Linguistics Program at Indonesia University, Jakarta, Indonesia. His current interests are on issues related to cultural linguistics, morphology, and discourse analysis. He is also actively participating in national and international linguistics seminars.

Mahyuni is a professor at the Language and Art Education Program, Teachers' Training and Education Faculty, Mataram University, Lombok, Indonesia. He accomplished his master degree at Macquarie University, New South Wales, Australia in 1994 and doctoral degree at the Department of Linguistics and Applied Linguistics, University of Melbourne, Victoria, Australia in 2004. His current interests are on issues related to language and culture, language and gender, and discourse analysis.

I Wayan Simpen is a professor in Linguistics at Udayana University, Bali, Indonesia. He accomplished his master degree in 1995 at the Linguistics Program in Indonesia University, Jakarta, Indonesia and doctoral degree at the Linguistics Program of Udayana University, Bali, Indonesia in 2008. His current interests are on issues related to ecolinguistics, cultural linguistics and pragmatics. 